\title{
A New Diabetic Management Using Standardized Diet and Post Meal Plyometric Exercise
}

\author{
Dwipajati $^{1}$ \\ Clinical Nutrition, Department of Nutritional Science, \\ Universitas Sebelas Maret \\ Surakarta, Indonesia \\ dwipajati@yahoo.co.id
}

\author{
Dono Indarto ${ }^{2}$ \\ Department of Physiology, Medical Faculty \\ Universitas Sebelas Maret \\ Surakarta, Indonesia \\ donoind323@gmail.com
}

\author{
Paramasari Dirgahayu ${ }^{3}$ \\ Faculty of Medicine \\ Universitas Sebelas Maret, \\ Surakarta, Indonesia \\ paramasari123@gmail.com
}

\begin{abstract}
Prevalence of diabetes mellitus in the world has increased significantly in the last decades. Post meal physical exercise studies could improves blood glucose levels in diabetic patients. Plyometric exercise is a simple body movement that usually uses in body weight management. Therefore the aim of this study was to investigate the effect of combination of diet and post meal plyometric exercise on blood glucose levels of diabetic patients. A total of 19 diabetic patients were participated in this randomized control trial study. The control (C) group (10 patients) only received a standardized diet was determine using the IEA recommendation and the treatment (T) group ( 9 patients) received the same diet and post meal jumping jack for 2 min. Fasting and postprandial blood glucose levels were measured in the $1^{\text {st }}$ and $7^{\text {th }}$ days of intervention. Mean BMI in $\mathrm{C}$ and $\mathrm{T}$ groups was $>25 \mathrm{~kg} / \mathrm{m}^{2}$. Reduced mean blood glucose levels in 0 min of the $C$ group $(146.90 \pm 68.34 \mathrm{mg} / \mathrm{dL})$ in $7^{\text {th }}$ day intervention were significant lower than 1 st day $(198.70 \pm 91.64 \mathrm{mg} / \mathrm{dL})$. While mean blood glucose levels of the T group in 0,30 and $60 \mathrm{~min}$ at $7^{\text {th }}$ day intervention $(143 \pm 53.95 ; 203.78 \pm 79.64 ; 237 \pm 72.76 \mathrm{mg} / \mathrm{dL})$ were significanly lower than $1^{\text {st }}$ day intervention $(179.78 \pm 74.17$; $254.67 \pm 102.73 ; 287.89 \pm 109.44 \mathrm{mg} / \mathrm{dL}$ ) respectively. Standardized diet and post meal plyometric exercise can decrease postprandial blood glucose levels in diabetic patients. Further investigation are required to find appropriate type and duration of post meal exercise, based on individual patients with diabetes.
\end{abstract}

Keywords- plyometric exercise; standardized diet; diabetes mellitus; blood glucose levels

\section{INTRODUCTION}

Diabetes Mellitus (DM) is one of non-communicable diseases that rapidly increases in the last decade and becomes a serious threat on global health population. The International Diabetes Federation (IDF) has reported that 5.6\% adults (20-79 years old) in the world has diabetes mellitus and it is estimated to rise 1.3 times in 2045. Type-2 diabetes mellitus is very common found in community in either developing or developed countries [1]. The prevalence of DM in Indonesia is the sixth top rank around the world which is approximately $3 \%$
Indonesian people living with diabetes. In addition, many diabetic patients have poor glycaemic control which leads to increase complications and to decrease their quality of life. Therefore it will increase global mortality rate and national health costs [2].

Some international diabetes organizations have recommended that non-pharmacology therapy through diet modification and physical exercise are the good way to achieve a normal glycaemic control [2]-[4]. Indonesian Endocrinology Association (IEA) has also developed 3 basic principles of recommended dietary management for diabetic patients (regularly eating time, consumed properly food amount and type) [5]. However, the majority of diabtetic patients just reduces their meal frequency and food intake with high glycaemic index [6].

Furthermore, diabetic patients should do a physical exercise at least three times/week with 30-45 min duration and moderate intensity to enhance reduction of their blood glucose levels [3]. Recent studies have reported that exercise after meal can improve blood glucose levels of diabetic patients through insulin sensitivity and muscular glucose uptake[7]-[11] Plyometric exercise or jumping training which consists of jumping, bounding and hooping is primarily used by athletes to improve their muscle strength and speed performance [12], [13]. The jumping jack is easyly done by everyone, in everywhere and every time. Lately, this exercise has become popular for weight loss program [14]. Therefore the aim of this study was to investigate the effect of combination of standardized diet and post meal plyometric exercise on blood glucose levels in diabetic patients

\section{METHODS}

\section{A. Experimental design and Participants}

This study used a randomized control trial with pre-post-test control group design. The research protocol was approved by the Ethics Committee of Dr. Moewardi General Hospital with 
Number 502/ VI/HREC/ 2017. Members of Diabetic Association in two Primary Health Cares in Tasikmadu and Kartasura Districts were participated in this study. Eligible participants had to match with subject criterias: aged 40-65 years old, never got diet therapy, did not smoke, had $>130$ $\mathrm{mg} / \mathrm{dL}$ fasting blood glucose and $>180 \mathrm{mg} / \mathrm{dL}$ postprandial blood glucose levels, had low physical exercise (30-45 minutes/day and <3 times/week), and took regularly oral hypoglycaemic drugs (metformin, sulfonylurea derivatives, or combination of both drugs).

Our experiment was done for 2 weeks, which was commenced with nutrition counselling session in the first week and the following week all participants got standardized diet and did the jumping jack. Firstly, 19 selected participants wrote their informed consent and had to attend the nutrition counselling session. Their body weight (BW) was then measured using a SMIC digital personal scale (China) and their body height used a GEA Medical SH-2A (China). Blood glucose levels were measured using Semi-Automatic Chemistry Analyser BM-sp7000S (China) and blood pressure used GEA Mercury Sphygmomanometer (China).

Before intervention, the participants were randomly divided into two groups: 10 participants in control (C) and 9 participants in treatment group $(\mathrm{T})$. The $\mathrm{C}$ group received a standardized diet only and $\mathrm{T}$ group received a standardized diet and performed 5 min post meal jumping jack for $2 \mathrm{~min}$. Both treatments was done at the Primary Health Cares in the first and seventh days of intervention. All participants had to do both treatments at their home for other days of intervention.

\section{B. Standardized Diet}

Participants consumed a standardized diet that consisted of carbohydrate (mixure of brown and white rice), protein (tofu, egg or meat), $100 \mathrm{~g}$ mixed vegetables, and 1 piece of banana. Total energy and nutrient values of the standardized diet were calculated using the IEA equation (Table 1) and adjusted to energy requirement of each participants. Their daily food intake were regularly recorded in the diet note book, asked by enumerator in the first and seventh days of intervention and monitored by phone from the second to sixth days .

TABLE I

ENERGY AND MACRONUTRIENT CONTENTS IN THE STANDARDIZED DIET

\begin{tabular}{|c|c|c|c|c|c|c|}
\hline \multirow{2}{*}{ Group } & \multirow{2}{*}{ Intervention (Day) } & \multicolumn{5}{|c|}{ Nutrition Fact (Mean \pm SD) } \\
\hline & & E (kcal) & $\mathbf{P}(\mathbf{g})$ & L (g) & CH (g) & $\mathbf{F}(\mathrm{g})$ \\
\hline \multirow{3}{*}{$\mathrm{C}$} & $1^{\text {st }}$ & $\begin{array}{c}529.34 \\
\pm\end{array}$ & $\begin{array}{c}18.43 \\
\pm\end{array}$ & $\begin{array}{c}18.42 \\
\pm\end{array}$ & $\begin{array}{c}76.90 \\
\pm\end{array}$ & $\begin{array}{c}7.30 \\
\pm\end{array}$ \\
\hline & & 63.54 & 3.51 & 2.16 & 8.90 & 0.55 \\
\hline & $7^{\text {th }}$ & $\begin{array}{c}570.76 \\
\pm \\
68.50\end{array}$ & $\begin{array}{c}18.99 \\
\pm \\
4.15\end{array}$ & $\begin{array}{c}22.53 \\
\pm \\
2.52\end{array}$ & $\begin{array}{c}76.74 \\
\pm \\
8.83\end{array}$ & $\begin{array}{c}7.80 \\
\pm \\
0.55\end{array}$ \\
\hline \multirow{2}{*}{$T$} & $1^{\text {st }}$ & $\begin{array}{c}510.14 \\
\pm \\
73.18\end{array}$ & $\begin{array}{c}17.29 \\
\pm \\
3.45\end{array}$ & $\begin{array}{c}17.74 \\
\pm \\
1.97\end{array}$ & $\begin{array}{c}75.69 \\
\pm \\
11.30\end{array}$ & $\begin{array}{c}7.12 \\
\pm \\
0.64\end{array}$ \\
\hline & $7^{\text {th }}$ & $\begin{array}{c}550.23 \\
\pm \\
77.15\end{array}$ & $\begin{array}{c}17.69 \\
\pm \\
3.94\end{array}$ & $\begin{array}{c}21.78 \\
\pm \\
2.24\end{array}$ & $\begin{array}{c}74.56 \\
\pm \\
11.23\end{array}$ & $\begin{array}{c}7.62 \\
\pm \\
0.64\end{array}$ \\
\hline
\end{tabular}

E, energy; P, protein; L, fat; $C H$, carbohydrate; $F$, fiber;g, gram

\section{Blood Glucose Test and Statistical Analysis}

Before nutrition counselling session, fasting and $2 \mathrm{~h}$ postprandial blood glucose levels of all participants were measured. The next blood glucose levels were measured in 0 , 30 and 60 minutes after meal in the first and seventh days of intervention using the same device in earlier measurement. All collected data were presented as Mean \pm SD whereas statistical analysis were performed using independent and paired t-tests in IBM SPSS for Windows Version 20 with p value $<0.05$.

\section{RESULTS}

Table II indicated the characteristics of all participants in this study. Control group had higher average of BW, BMI, fasting and $2 \mathrm{~h}$-post prandial glucose levels, and protein intake than that of $\mathrm{T}$ group although it did not differ significantly. While lower average of age, blood pressure, energy, fat and fiber intake was observed in $\mathrm{C}$ group, compared with $\mathrm{T}$ group but it did not reach significant differences. All participants in both groups had overweight with low physical exercise.

TABLE II

BASIC CHARACTERISTICS OF DIABETIC PATIENTS IN CONTROL AND TREATMENT GROUPS

\begin{tabular}{|c|c|c|c|}
\hline \multirow[t]{2}{*}{ Variable } & $\begin{array}{c}\text { Control } \\
(\mathrm{n}=10)\end{array}$ & $\begin{array}{c}\text { Treatment } \\
(\mathrm{n}=9)\end{array}$ & \multirow{2}{*}{$\begin{array}{c}p \\
\text { value }\end{array}$} \\
\hline & \multicolumn{2}{|c|}{ Mean \pm SD } & \\
\hline Age, years & $53.50 \pm 7.28$ & $54.11 \pm 6.07$ & 0.42 \\
\hline BW, kg & $62.99 \pm 9.17$ & $58.03 \pm 8.27$ & 0.23 \\
\hline BMI, $\mathrm{kg} / \mathrm{m}^{2}$ & $26.79 \pm 2.73$ & $25.88 \pm 3.77$ & 0.28 \\
\hline Duration of DM & $4.65 \pm 3.48$ & $4.05 \pm 3.71$ & 0.23 \\
\hline $\begin{array}{c}\text { Physical exercise } \\
(\mathrm{min} / \text { week })\end{array}$ & $60 \pm 12$ & $77 \pm 16$ & 0.11 \\
\hline $\begin{array}{c}\text { Fasting glucose, } \\
\text { mg/dL }\end{array}$ & $212.5 \pm 103.88$ & $205.88 \pm 99.54$ & 0.47 \\
\hline $\begin{array}{l}\text { 2h-post prandial } \\
\text { glucose, } \mathrm{mg} / \mathrm{dL}\end{array}$ & $316.9 \pm 154.6$ & $305.07 \pm 150.46$ & 0.45 \\
\hline $\begin{array}{c}\text { Systolic blood } \\
\text { pressure, } \mathrm{mmHg}\end{array}$ & $128 \pm 18.74$ & $131.11 \pm 9.28$ & 0.65 \\
\hline $\begin{array}{c}\text { Diastolic blood } \\
\text { pressure, } \mathrm{mmHg}\end{array}$ & $85 \pm 8.5$ & $88.89 \pm 9.28$ & 0.36 \\
\hline \multicolumn{4}{|l|}{ Recall; } \\
\hline Energy (kcal) & $916.6 \pm 375.09$ & $981.411 \pm 342.59$ & 0.69 \\
\hline Protein $(g)$ & $34.11 \pm 19.96$ & $30.28 \pm 12.83$ & 0.62 \\
\hline Lipid (g) & $31.96 \pm 19.67$ & $39.8 \pm 14.99$ & 0.34 \\
\hline $\begin{array}{c}\text { Carbohydrate } \\
\text { (g) }\end{array}$ & $129.31 \pm 43.37$ & $129.1 \pm 54.12$ & 0.99 \\
\hline Fiber $(g)$ & $6.72 \pm 1.96$ & $6.99 \pm 3.91$ & 0.86 \\
\hline
\end{tabular}

In comparison with blood glucose levels before intervention, lower mean blood glucose levels was found in $\mathrm{C}$ and $\mathrm{T}$ groups (Figure 1). In the $1^{\text {st }}$ day intervention, the average of blood glucose levels in 0 min was similar between C $(255.6 \pm 109.53$ $\mathrm{mg} / \mathrm{dL})$ and $\mathrm{T}$ groups $(254.67 \pm 102.73 \mathrm{mg} / \mathrm{dL})$. Whereas mean blood glocose levels in 30 and 60 min of C group (198.7 \pm 91.64 , and $298.60 \pm 109.53 \mathrm{mg} / \mathrm{dL}$ ) were higher than $\mathrm{T}$ group $(179.78 \pm 74.17$; and $287.89 \pm 109.44 \mathrm{mg} / \mathrm{dL})$ but it was not significantly different $(\mathrm{p}=0.99$ and $\mathrm{p}=0.83)$. 


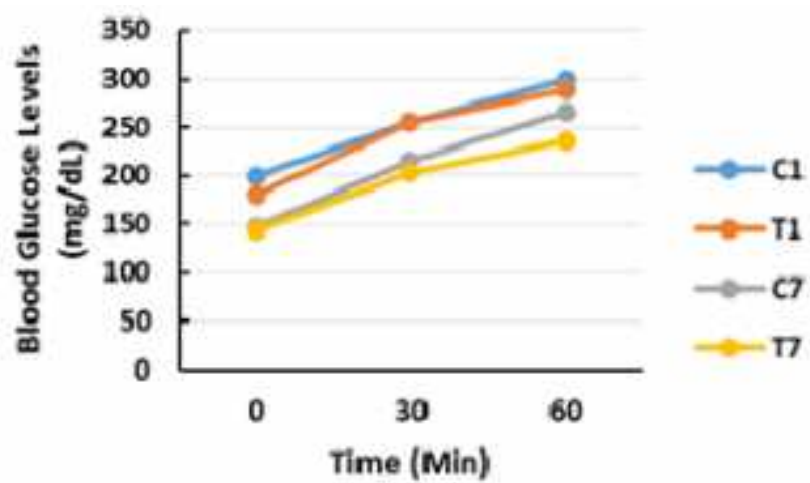

Figure 1. The mean blood glucose levels in $1^{\text {st }}$ and $7^{\text {th }}$ days after nutrition counselling and post meal exercise $(\mathrm{C} 1$ and $\mathrm{T} 1$ were group in the $1^{\text {st }}$ day intervention while $\mathrm{C} 2$ and $\mathrm{T} 2$ were group in the $7^{\text {th }}$ day intervention)

In the $7^{\text {th }}$ day intervention, the average of blood glucose levels $(0,30$ and $60 \mathrm{~min})$ in both groups was lower than that of the $1^{\text {st }}$ day intervention. All mean blood glucose levels in $\mathrm{T}$ group at the $7^{\text {th }}$ day intervention were significantly lower than that of the same group in the $1^{\text {st }}$ day intervention $(\mathrm{p}=0.03 ; \mathrm{p}=0.02$ and $\mathrm{p}=0.03$ ) respectively. Higher significant reduction of mean blood glucose levels in 0 min was observed in the $C$ group $(146.90 \pm 68.34 \mathrm{mg} / \mathrm{dL})$ with $\mathrm{p}=0.04$. Mean blood glucose levels in $\mathrm{C}$ group after treatment did not significantly differ from mean blood glucose levels in T group.

Figure 2 showed that $\Delta$ blood glucose levels in $\mathrm{T}$ group were higher than $\Delta$ blood glucose levels in $\mathrm{C}$ group in different times except in $0 \mathrm{~min}$ blood glucose levels. C group had lower $\Delta 0$ min blood glucose levels compared with $\mathrm{T}$ group $(-51.80$ vs $-36.78 \mathrm{mg} / \mathrm{dL})$ with $\mathrm{p}=0.58$. In contrast with 0 min blood glucose levels, $\mathrm{T}$ group had higher $\Delta$ blood glucose levels in 30 and 60 min than in $\mathrm{C}$ group ( $\mathrm{p}=$ 0.72 and 0.62 respectively).

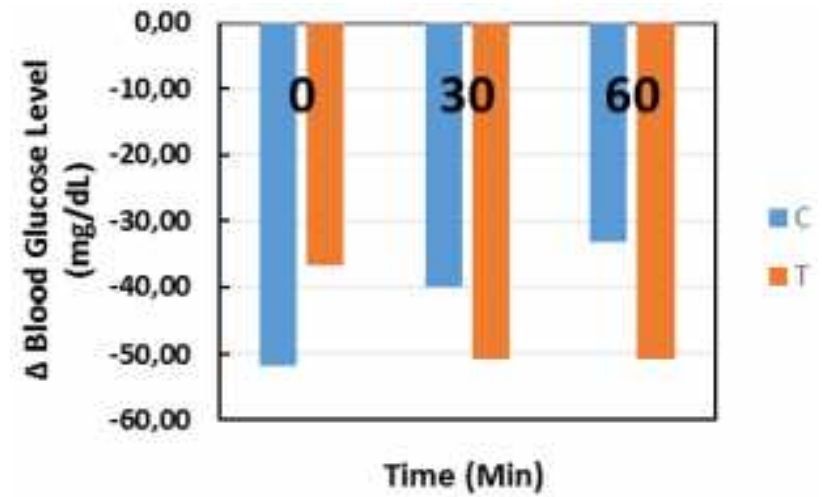

Figure 2. The mean $\Delta$ blood glucose levels after intervention between $\mathrm{C}$ and $\mathrm{T}$ groups.
TABLE III

THE AVERAGE OF ENERGY AND MACRONUTRIENT INTAKES IN C AND T GROUPS AFTER INTERVENTION

\begin{tabular}{|c|c|c|c|c|}
\hline & \multirow{2}{*}{$\begin{array}{l}\text { Daily Needs of } \\
\text { Enery and } \\
\text { Macronutrients }\end{array}$} & \multicolumn{2}{|c|}{ Intake (Days) } & \multirow[t]{2}{*}{ p value } \\
\hline & & 1 & 7 & \\
\hline \multicolumn{5}{|l|}{ C Group } \\
\hline $\mathrm{E}(\mathrm{Cal})$ & $1435.6 \pm 300.9$ & $\begin{array}{c}1301 \pm 307.6 \\
(90.6 \%)\end{array}$ & $\begin{array}{c}1241.5 \pm 224.3 \\
(86.5 \%)\end{array}$ & 0.61 \\
\hline$P(g)$ & $71.8 \pm 15.1$ & $\begin{array}{c}43.4 \pm 10.4 \\
(60.4 \%)\end{array}$ & $\begin{array}{l}41.3 \pm 9.1 \\
(57.5 \%)\end{array}$ & 0.63 \\
\hline $\mathrm{L}(\mathrm{g})$ & $39.8 \pm 8.36$ & $\begin{array}{l}49.7 \pm 18.1 \\
(124.6 \%)\end{array}$ & $\begin{array}{c}39.7 \pm 11.6 \\
(99.7)\end{array}$ & 0.20 \\
\hline $\mathrm{C}(\mathrm{g})$ & $197.4 \pm 41.4$ & $\begin{array}{c}178.5 \pm 38.1 \\
(90.4)\end{array}$ & $\begin{array}{c}185.8 \pm 33.1 \\
(94.1)\end{array}$ & 0.62 \\
\hline $\mathrm{F}(\mathrm{g})$ & $20 \pm 0$ & $\begin{array}{c}13.6 \pm 3.9 \\
(68 \%)\end{array}$ & $\begin{array}{l}14.1 \pm 4.4 \\
(70.5 \%)\end{array}$ & 0.74 \\
\hline \multicolumn{5}{|l|}{ T Group } \\
\hline $\mathrm{E}(\mathrm{Cal})$ & $1354.1 \pm 265.3$ & $\begin{array}{c}988.6 \pm 372.4 \\
(73 \%)\end{array}$ & $\begin{array}{c}1129 \pm 394.3 \\
(83.2 \%)\end{array}$ & 0.31 \\
\hline$P(g)$ & $67.7 \pm 13.3$ & $\begin{array}{c}28 \pm 9.3 \\
(41.4 \%)\end{array}$ & $\begin{array}{c}36.5 \pm 14.7 \\
(53.9 \%)\end{array}$ & 0.07 \\
\hline $\mathrm{L}(\mathrm{g})$ & $37.6 \pm 7.4$ & $\begin{array}{c}30.3 \pm 15.2 \\
(80.6 \%)\end{array}$ & $\begin{array}{l}39.6 \pm 18.9 \\
(105.3 \%)\end{array}$ & 0.23 \\
\hline $\mathrm{C}(\mathrm{g})$ & $186.2 \pm 36.5$ & $\begin{array}{c}155.7 \pm 68.2 \\
(83.6 \%)\end{array}$ & $\begin{array}{c}163 \pm 48.6 \\
(87.5)\end{array}$ & 0.74 \\
\hline$F(g)$ & $20 \pm 0$ & $\begin{array}{c}11.4 \pm 5.7 \\
(57 \%)\end{array}$ & $\begin{array}{l}13.9 \pm 5.6 \\
(69.5 \%)\end{array}$ & 0.33 \\
\hline
\end{tabular}

E: Energy; P: Protein; L: Lipid; C: Carbohydrate; F: Fiber

Energy and macronutrients intake in both group increased after nutrition counselling and post meal exercise except protein and lipid intake in $\mathrm{C}$ group (Table III). Total energy generated from all macronutrient intake in both groups did not reach $100 \%$, compared with calculated daily needs of all participants. In both groups, carbohydrate and fiber intake increased $2.5-12.5 \%$ after $7^{\text {th }}$ day intervention, compared with the $1^{\text {st }}$ day intervention although it was not significant difference. Reduced energy, protein and lipid intake was insignificantly observed in $\mathrm{C}$ group after the $1^{\text {st }}$ and $7^{\text {th }}$ days intervention which varied from 2.9 to $24.9 \%$. On the other hand, 10-24.7\% increased energy, protein and lipid intake was found in $\mathrm{T}$ group after the $1^{\text {st }}$ and $7^{\text {th }}$ days intervention but it was not statistically diferent.

\section{IV.DISCUSSION}

In the present study we have evaluated energy and macronutrient intake in diabetic patients with overweight. In general, they have DM for several years ago, low physical exercise, uncontrolled blood glucose levels, low daily intake, and no metabolic syndrome. After nutrition counselling and post meal exercise, all diabetic patients have increased daily food intake especially fiber and reduced blood glucose levels. However increased energy and macronutrient intake in both groups were below than the recommended diabetic daily needs. Furthermore, more reduction of blood glucose levels and more increase of macronutrient intake are appearently seen in diabetic patients who got standarized diet and post meal physical exercise. These findings suggest that non pharmacological therapy is able to control blood glucose levels without administration of oral diabetic drugs. 
Some diabetic patients have inappropiate perception for their diet. They restrict rice and sweetened foods and decrease meal frequency. Unfortunately, they still consume other carbohydrate sources like cassava, sweet potatoes, noodles, and bread during their snack time. That's why their blood glucose levels are above than the normal blood glucose levels before and after meal times (Table II). In this present study, we made a standardized diet (Table I) according to IEA (2015) Our data showed that nutrition counselling could reduce blood glucose levels in all diabetic patients. We controlled and monitor their diet through short message services or telephone. They could prepare their own meals according to diet recommendation issued by the IEA. Results of our study are in agreement with other studies conducted in Taiwan and Italy. Better glycemic control can be achieved by attending nutrition education and implementing self-care behaviour [15]. The other study reported that more dietary adherence is found in Italian diabetic patients who individually chose popular/ commercial diet programs, compared with Italian diabetic patients who got diet program from healthcare providers [16].

Although daily intake in all diabetic patients increased after intervention, increased fibers intake plays an important role in glucose homeostatis. Dietary fiber consumption will be fermented by human microflora in the large intestine which produce short chain fatty acids (SCFAs) like acetate, propionate and butyrate [17], [18]. From cellular and molecular aspects, SCFA provides 10\% alternative energy fuel and increases free fatty acid (FFA) oxidation, glucose uptake in human muscles and adiposes, glucagon like peptide 1(GLP-1) hormon in the colon, and insulin secretion in the beta cell pancreas [19], [20]. Therefore increased fiber consumption may result in reduction of blood glucose levels and weight loss in diabetic patients with overweight.

Our study showed that jumping jack after meal can reduce post prandial blood glucose levels in diabetics patients. Our results support a recent study that post meal exercise for $15 \mathrm{~min}$ in diabetic patients lower more blood glucose levels, compared with diabetic patients who did one time daily exercise [21]. Contrasting with our study, combination of aerobic exercise (cycling) and resistance training for 60 minutes in $3 x /$ week could also improve glycemic control, lipid profile, blood pressure and Insulin receptor substrate 1 (IRS-1) expression in Brazilian diabetic patients [22]. Similar outcome was also observed in a healthcare study conducted in Korean diabetic patients with low and moderate intensities of aerobic exercise (walking for 30 minutes in five times/week). Those exercises could improve glycaemic control and prevent DM complication [23]. However our study did not include diabetic patients group with one-time daily exercise. Therefore we can not conclude that post meal jumping jack reduce more blood glucose levels than one-time daily exercise.

Nutrition counselling in our study has a positive effect in terms of reduction of fasting blood glucose levels but low effect in 1-h postprandial blood glucose levels in diabetic patients (>200 mg/dL). Jumping jack-added diet program after meal time is able to reduce around $30 \mathrm{mg} / \mathrm{dL}$ post prandial blood glucose levels in diabetic patients. This exercise may stimulate glucose uptake by upregulation of GLUT-4 transporter and enhancement of mitochondrial function and biogenesis [24], [25]. Our result is in accordance with Pahra's study but their result indicated that post meal fast walking for 15 min could decrease $80 \mathrm{mg} / \mathrm{dL}$ blood glucose levels after 60 days [21]. Lower decreased blood glucose levels in our study are more likely related to different type and duration of physical exercise. Further studies are therefore required for improvement of physical exercise type and duration to achieve controlled blood glucose levels and to increase weight loss in diabetic patients with overweight.

\section{CONCLUSIONS}

A combination of nutrition counselling and post meal jumping jack can reduce more blood glucose levels in diabetic patients, compared with diabetic patients with nutrition counselling only. Diabetic patients should follow recommended standard diet and post meal exercise to improve their glycaemic control.

\section{ACKNOWLEDGMENT}

We would like to thank all diabetic patients for their participation on this study, dr. Isti Widodo and dr. Ita Kusumawati for giving permission to do this study, some nurses for taking blood sampels, laboratory analysts for measurement of blood glucose levels and enumerators for helping data collection.

\section{REFERENCES}

[1] D. R. Whiting, L. Guariguata, C. Weil, and J. Shaw, "IDF Diabetes Atlas: Global estimates of the prevalence of diabetes for 2011 and 2030," Diabetes Res. Clin. Pract., vol. 94, no. 3, pp. 311-321, Dec. 2011.

[2] "Global report on diabetes," World Health Organization, Geneva, Switzerland, 2016.

[3] International Diabetes Federation, IDF Diabetes Atlas Eighth edition 2017,8 th ed. International Diabetes Federation.

[4] ADA, "Standard Medical Care on Diabetes." ADA, 2017.

[5] PERKENI, Konsensus Pengelolaan dan Pencegahan Diabetes Melitus Tipe 2 di Indonesia 2015. Jakarta: Perkeni, 2015.

[6] S. P. Anuruddhika Subhashinie Senadheera, S. Ekanayake, and C. Wanigatunge, "Dietary Habits of Type 2 Diabetes Patients: Variety and Frequency of Food Intake," J. Nutr. Metab., vol. 2016, pp. 1-6, 2016.

[7] H. Honda et al., "Stair climbing/descending exercise for a short time decreases blood glucose levels after a meal in people with type 2 diabetes," BMJ Open Diabetes Res. Care, vol. 4, no. 1, p. e000232, 2016.

[8] P. C. Dempsey et al., "Benefits for Type 2 Diabetes of Interrupting Prolonged Sitting With Brief Bouts of Light Walking or Simple Resistance Activities," Diabetes Care, vol. 39, no. 6, pp. 964-972, Jun. 2016.

[9] A. N. Reynolds, J. I. Mann, S. Williams, and B. J. Venn, “Advice to walk after meals is more effective for lowering postprandial glycaemia in type 2 diabetes mellitus than advice that does not specify timing: a randomised crossover study," Diabetologia, vol. 59, no. 12, pp. 2572 2578, Dec. 2016.

[10] Z. C. Thent, S. Das, and L. J. Henry, "Role of Exercise in the Management of Diabetes Mellitus: the Global Scenario," PLOS ONE, vol. 8, no. 11, p. e80436, Nov. 2013.

[11] J.-W. van Dijk, K. Tummers, C. D. A. Stehouwer, F. Hartgens, and L. J. C. van Loon, "Exercise Therapy in Type 2 Diabetes: Is daily exercise required to optimize glycemic control?," Diabetes Care, vol. 35, no. 5, pp. 948-954, May 2012.

[12] J. Kümmel, J. Bergmann, O. Prieske, A. Kramer, U. Granacher, and M. Gruber, "Effects of conditioning hops on drop jump and sprint 
performance: a randomized crossover pilot study in elite athletes," BMC Sports Sci. Med. Rehabil., vol. 8, no. 1, Dec. 2016.

[13] G. Davies, B. L. Riemann, and R. Manske, "Current concepts of plyometric exercise," Int. J. Sports Phys. Ther., vol. 10, no. 6, p. 760, 2015.

[14] S. R. Barillas et al., "Repeated Plyometric Exercise Attenuates Blood Glucose in Healthy Adults," Int. J. Exerc. Sci., vol. 10, no. 7, p. 1076 , 2017.

[15] C.-M. Ouyang, J. T. Dwyer, P. F. Jacques, L.-M. Chuang, C. F. Haas, and K. Weinger, "Determinants of dietary self-care behaviours among Taiwanese patients with type 2 diabetes," Asia Pac. J. Clin. Nutr., vol. 24, no. 3, pp. 430-437, 2015.

[16] V. Ponzo et al., "Self-reported adherence to diet and preferences towards type of meal plan in patient with type 2 diabetes mellitus. A cross-sectional study," Nutr. Metab. Cardiovasc. Dis., vol. 27, no. 7, pp. 642-650, Jul. 2017.

[17] J. Slavin, "Fiber and Prebiotics: Mechanisms and Health Benefits," Nutrients, vol. 5, no. 4, pp. 1417-1435, Apr. 2013.

[18] M. Conlon and A. Bird, "The Impact of Diet and Lifestyle on Gut Microbiota and Human Health," Nutrients, vol. 7, no. 1, pp. 17-44, Dec. 2014.

[19] G. den Besten, K. van Eunen, A. K. Groen, K. Venema, D.-J. Reijngoud, and B. M. Bakker, "The role of short-chain fatty acids in the interplay between diet, gut microbiota, and host energy metabolism," J. Lipid Res., vol. 54, no. 9, pp. 2325-2340, Sep. 2013.

[20] C. S. Byrne, E. S. Chambers, D. J. Morrison, and G. Frost, "The role of short chain fatty acids in appetite regulation and energy homeostasis," Int. J. Obes., vol. 39, no. 9, pp. 1331-1338, Sep. 2015.

[21] D. Pahra, N. Sharma, S. Ghai, A. Hajela, S. Bhansali, and A. Bhansali, "Impact of post-meal and one-time daily exercise in patient with type 2 diabetes mellitus: a randomized crossover study," Diabetol. Metab. Syndr., vol. 9, no. 1, Dec. 2017.

[22] M. L. M. P. Jorge et al., "The effects of aerobic, resistance, and combined exercise on metabolic control, inflammatory markers, adipocytokines, and muscle insulin signaling in patients with type 2 diabetes mellitus," Metabolism, vol. 60, no. 9, pp. 1244-1252, Sep. 2011.

[23] J.-H. Park and Y.-E. Lee, "Effects of exercise on glycemic control in type 2 diabetes mellitus in Koreans: the fifth Korea National Health and Nutrition Examination Survey (KNHANES V)," J. Phys. Ther. Sci., vol. 27, no. 11, pp. 3559-3564, 2015.

[24] E. A. Richter and M. Hargreaves, "Exercise, GLUT4, and Skeletal Muscle Glucose Uptake,” Physiol. Rev., vol. 93, no. 3, pp. 993-1017, Jul. 2013.

[25] K. I. Stanford and L. J. Goodyear, "Exercise and type 2 diabetes: molecular mechanisms regulating glucose uptake in skeletal muscle," Adv. Physiol. Educ., vol. 38, no. 4, pp. 308-314, Dec. 2014. 